\title{
Obesity and Diabetes as Main Risk Factors for Stillbirth in a Population from Northeastern Mexico
}

Kiabeth Robles Espinoza ( $\sim$ kiabethre@gmail.com )

Hospital Universitario Dr Jose Eleuterio Gonzalez https://orcid.org/0000-0002-1036-3249

Graciela Arelí López Uriarte

Hospital Universitario Dr Jose Eleuterio Gonzalez https://orcid.org/0000-0001-8562-0847

Gloria Beatriz García Castañeda

Hospital Universitario Dr Jose Eleuterio Gonzalez

Iris Torres Muñoz

Hospital Universitario Dr Jose Eleuterio Gonzalez

José de Jesús Lugo Trampe

Hospital Universitario Dr Jose Eleuterio Gonzalez

Guillermo Elizondo Riojas

Hospital Universitario Dr Jose Eleuterio Gonzalez https://orcid.org/0000-0002-9555-430X

Oralia Barboza Quintana

Hospital Universitario Dr Jose Eleuterio Gonzalez

Marco Ponce Camacho

Hospital Universitario Dr Jose Eleuterio Gonzalez

Abel Guzmán López

Hospital Universitario Dr Jose Eleuterio Gonzalez

Laura Martínez de Villareal

Hospital Universitario Dr Jose Eleuterio Gonzalez https://orcid.org/0000-0003-1442-9089

\section{Research Article}

Keywords: Stillbirth, risk factor, obesity, diabetes

Posted Date: July 16th, 2021

DOI: https://doi.org/10.21203/rs.3.rs-647477/v1

License: (9) (1) This work is licensed under a Creative Commons Attribution 4.0 International License. Read Full License 


\section{Abstract}

Purpose Stillbirth is an important health problem in obstetrics practice. In Mexico, half of the stillbirths have an explainable cause. The aim of this study was to detect potential stillbirth risk factors and etiology by implementing a multidisciplinary workup at the Hospital Universitario "Dr. José Eleuterio González". Methods This is a prospective, descriptive, observational study that included stillbirths from the Obstetrics Service from October 1st, 2019 to May 25, 2020. Evaluation strategies included a complete maternal medical history, physical examination of the fetus, and a photographic medical record. A stillbirth needed to have either a prenatal ultrasound, or a postnatal x-ray, and if possible, a fetal autopsy. Multiplex Ligation Probe Amplification (MLPA) was performed with an umbilical cord sample. Results Thirty-three stillbirths were reported; 21 were included in the analysis. Eleven mothers (52.3\%) had known risk factors for stillbirth, mainly elevated body mass index and diabetes. On physical examination, external birth defects were found in 8 fetuses (38\%). X-ray was performed in 14 cases (66\%). Alterations were detected as a probable etiologic cause just in one. All cases underwent MLPA, which were reported negative. Three cases had criteria for autopsy. Findings were inconclusive to determine etiology. Conclusion Diabetes and obesity were the most frequent risk factors associated with stillbirth in this Mexican population. These factors are preventable by implementing strategies that lead to better prenatal care.

\section{Declarations}

\section{Funding}

The project was funded with resources of the Genetics Department as well as the Radiology and Pathology Departments of the Hospital Universitario “Dr. José Eleuterio González,” Universidad Autónoma de Nuevo León.

\section{Conflicts of interest}

The authors declare that they have no conflicts of interest.

\section{Availability of data and material}

Data are available upon reasonable request

\section{Code availability}

Not applicable

\section{Author Contributions}

K Robles-Espinoza: Project development, sample collection, patient evaluation, data collection, tissue processing, data analysis, manuscript writing.

GA López-Uriarte: Project development, data analysis, manuscript writing/editing.

GB García-Castañeda: Tissue processing.

I Torres-Muñoz: Tissue processing and analysis.

JJ Lugo-Trampe: Tissue processing and analysis.

G Elizondo-Riojas: Project development

O Barbosa-Quintana: Project Development

M Ponce-Camacho: Project Development

A Guzmán-López: Project Development 
L Martinez de Villareal: Project development, data analysis, manuscript writing/editing.

\section{Ethics Approval}

The study was approved by the Ethics Committee of the Facultad de Medicina and Hospital Universitario, Universidad Autónoma de Nuevo León with registration number GN19-00004.

Consent to participate: Participants provided written consents for participation, use and storage of tissue samples.

Consent for publication: Participants provided written consent explaining protocol and usage of data for publication.

\section{Introduction}

Stillbirth is defined by the World Health Organization (WHO) as "death prior to the complete expulsion or extraction from its mother of a product of conception, irrespective of the duration of pregnancy." According to gestational age, it is considered a fetus of 22 weeks or that has reached a weight of 0.5 kilograms [1]. It is a devastating problem in obstetrics for families, society, and public health. It accounts for two-thirds of perinatal mortality [2].

Stillbirth occurs in 3 to 5 of every 1000 births [3]; however, these numbers might be underestimated because of inadequate registry in some countries and a lack of consensus in its classification and definition [4]. Developing countries report a higher incidence. Regions of Africa and Asia report an incidence of 28.7 and 25.5 for every 1000 births, respectively [5].

Stillbirth causes have been classified into different categories: maternal factors, fetal factors, or a combination of both. Suspected causes of stillbirth include genetic abnormalities, infection, fetal-maternal hemorrhage, and various medical conditions in the mother such as obesity, advanced maternal age, smoking, diabetes, hypertension, lupus, and thyroid diseases. Birth defects of chromosomal, monogenic, or multifactorial etiology have been described among the fetal factors. Combined factors include placental and umbilical cord pathologies [3,6,7].

It is difficult to be certain of the stillbirth etiology for several reasons. More than one cause may be involved, or some conditions might be associated but not directly causal. It is important to distinguish conditions that are mainly associations rather than causes [8]. An adequate workup for stillbirth has not been implemented. A lack of registry, consensus, comprehension about etiology, and ethical and emotional implications of some procedures might account for the absence of global stillbirth guidelines [8].

In general, a complete evaluation should have as a goal effective procedures to determine the cause and identify conditions that might be prevented. The use of a systematic evaluation, including postmortem examination, placental pathology, medical record abstraction, and maternal interview, has a higher potential of determining a true cause, as has been reported in some centers with an efficacy of 25 to $90 \%[2,8]$.

In Mexico, as in many other countries, half of the stillbirths have no explicable cause. Implementing a multidisciplinary workup that includes a complete clinical record, physical examination, autopsy, plain x-ray, cytogenetic or molecular studies permits adequate evaluation and the possibility of reaching an etiologic diagnosis, allowing the development of prevention strategies, and providing families with adequate genetic counseling $[3,7,9,10]$.

This study aimed to implement a multidisciplinary workup to identify the etiology and potential risk factors for stillbirth at a tertiary-care university hospital in Northeast Mexico.

\section{Methods}

This was a descriptive, observational prospective study of stillbirths from the Obstetrics Service of the Hospital Universitario “Dr. José Eleuterio González” from October 1, 2019, to May 25, 2020. Cases were collected by a resident of the Genetics 
Department who verified the inclusion criteria and obtained informed consent from the mother. The Ethics Committee of the Facultad de Medicina and Hospital Universitario of the Universidad Autonoma de Nuevo Leon approved the study.

Stillbirths of 22 weeks or more (early and late fetal deaths) with a fetus weight $\geq 0.5$ kilograms from adult mothers were included in the study. All participant mothers provided written informed consent for participation and use of biological material for further analysis. A Genetics department resident obtained the mother's complete medical history. After birth, a physical examination was performed on the stillborn, and a photographic record was obtained as part of every patients' file. If the parents consented and pathology requirements were fulfilled, an autopsy was performed.

The autopsy requirements were a period less than six hours from fetus extraction to the autopsy, a copy of the stillbirth certificate performed by the obstetrician, and a summary from the geneticist pinpointing the most important findings of the medical history, physical examination, and suspected diagnosis. If any of these was not achieved, a plain x-ray was used as an alternate study.

Fetuses with any of the procedures mentioned before or maceration grades IV and V (stillbirth scale) [11] were excluded. Inadequate or contaminated biological samples were eliminated.

Procedure

Cases needed to have an autopsy, a prenatal ultrasound, or a postnatal plain x-ray. Molecular studies were performed in all cases. A 1-cm tissue sample from the umbilical cord was obtained for DNA extraction using the Gentra Puregene DNA extraction kit. This sample was used to perform Multiplex Ligation Probe Amplification (MLPA) (SALSA MLPA Probemix P095 Aneuploidy, MRC Holland), which detects DNA sequences, and has probes for chromosomes $X, Y, 13,18$, and 21.

The data obtained were analyzed using quantitative and qualitative statistics to calculate mean, median, and range. Probable associations were evaluated for each case. SPSS v21 was used for statistical analysis.

\section{Results}

Thirty-three stillbirth cases were reported at the “Dr. José Eleuterio González" University Hospital from October 2019 to May 2020 , with a frequency of 7/1000 live births; of these, only 21 fulfilled the inclusion criteria. Six were lost due to delayed notification, three mothers were less than 18-years-old, two decided not to participate, and one was eliminated due to extreme maceration.

The maternal demographic characteristics are shown in Table 1. The maternal age range was 18 to 38 years (median $=25$ years); three were older than 35. Eleven mothers (52.3\%) had known risk factors for stillbirth; some had more than one. Four mothers (19\%) had pregestational diabetes with poor metabolic control before and during pregnancy. Overweight and obesity were found in 12 (57 \%) women. Three (25\%) were overweight (BMI = 25-29) and 9 (75\%) were obese (BMl> 30). None of the mothers had preconceptional folic acid intake.

Two were twin pregnancies. In both, the second baby was born without complications. None of the families participating had the antecedent of stillbirth. One had two previous abortions at five and eight weeks of gestation.

Of the stillbirths included in our study, 10 were a first pregnancy (47.6\%); 14 (66.6\%) occurred between 29 and 37 weeks of gestation. Pregnancy ended by vaginal delivery in 18 cases (85.7\%). Twelve of the stillbirths were female (57\%), and 9 (42.8\%) male. The stillbirths' weight was predominantly $>1000$ grams $(62 \%)$, and none of the stillbirths had low weight for gestational age. The degree of maceration was important for inclusion and physical examination. This evaluation was adequately performed in most cases since $76.1 \%$ presented grade I maceration. The demographics of the stillbirths are shown in Table 2. Seventeen mothers (81\%) had a prenatal ultrasound; nine (53\%) reported abnormalities (Table 3).

External birth defects were found in 8 fetuses (38\%) on physical examination; 5 had multiple malformations, 1 anencephaly, and 2 pes valgus deformity (Table 3 ). At initial evaluation, chromosomal alterations were suspected in two patients, and in 
another, a monogenic syndrome was considered.

X-ray was performed in 14 cases (66\%). Alterations were detected in one as a probable etiologic cause, finding pathognomonic signs of congenital syphilis.

All cases underwent MLPA, which was reported negative. Conventional cytogenetics was performed in 18 patients with an umbilical cord sample. Three had adequate cell growth and yielded normal results. Only three cases had criteria for autopsy; nevertheless, the findings were inconclusive for determining the cause of stillbirth.

\section{Discussion}

Although the stillbirth rate has declined in recent years, it is still an important obstetric health problem due to its association with increased perinatal mortality. Stillbirth rates remain high, especially in low and middle-income countries, where rates are 25 per 1000, ten times higher than in high-income countries.

In our study, the rate of fetal deaths was 7/1000, which is lower than the mean for Latin American countries (in 2015 rate was 8.1 per 1000 births, range 3.1-24.9) but is close to Mexico's average rate of 7.9/1000 [5]. However, problems in the notification of stillbirth and the study's duration could influence our incidence. A long-term evaluation should be performed for more accurate data. Nevertheless, it represents a public health issue for which identifying risk factors is important to propose prevention strategies.

From the major causes of stillbirths, we can point out the following: childbirth complications, multiple pregnancies, post-term pregnancy, maternal infections (malaria, syphilis, and HIV), maternal disorders (especially hypertension, obesity, and diabetes), fetal growth restriction, and congenital abnormalities. Several algorithms have been proposed for the study of stillbirth to identify possible causes of this fatal outcome of pregnancy.

In this multidisciplinary workup, we used different tools. The maternal medical history, physical examination, photographs, medical record, prenatal ultrasound, x-ray, or autopsy were obtained. MLPA was performed in all cases.

The correlation between maternal medical history and the description of birth defects in the fetus gave us information for possible risk factors in 16 cases, representing a usefulness of $76 \%$, higher than $26 \%$ reported by Pauli et al. [6] and Wojcik [9].

External physical examination is important for the detection of birth defects. This procedure must be performed by a medical professional who has been trained in dysmorphology. Nevertheless, the maceration grade should be between 0 and III to facilitate the examination [11]. This approach let us identify malformations in 8 cases. Macroscopic evaluation should complement an autopsy which is considered the most useful study for stillbirth since it allows identifying characteristics not observable by physical examination. A complete autopsy should include an analysis of the placenta and umbilical cord [8,9,11]. It can identify stillbirth etiology in about $90 \%$ of cases [9]. However, to maximize the autopsy's efficacy, it is important to consider the time from fetal death to the autopsy. The longer it takes to perform the autopsy, the less efficient it will be [9,14]. In our workup, only three autopsies were accomplished. The rest could not be achieved due to delayed notification, and in two cases, the mothers did not consent to the autopsy. It was difficult to assess the efficiency of the autopsy in our study with the data obtained, but the shortage of information obtained in those three cases may relate to a prolonged time from fetal death to evaluation.

Approximately $3 \%$ of prenatal ultrasounds detect an abnormality. This can range from minor to multiple defects, which can put the development of the fetus at risk [12]. The detection of anomalies in prenatal ultrasound can affect the pregnancy outcome, so it should be considered a part of the prenatal care of all women [13]. In the present study, 17 (53\%) women had a prenatal ultrasound, of which 9 (53\%) showed either fetal or placental findings of relevance for diagnosis, such as holoprosencephaly, anencephaly, hydrops fetalis, and placenta previa. The efficiency of prenatal ultrasound for detecting birth defects has been reported as $3 \%$ [12], with our rate of detection being higher. 
A plain X-ray is also considered an adequate study when an autopsy cannot be performed [9]. It can identify stillbirth etiology in about $16 \%$ [6]. However, a plain X-ray might be more efficient when skeletal pathology is suspected. We only detected suggestive findings in one patient (4.8\%) with congenital syphilis.

Genetic etiology of stillbirth can be found in 25-35\% [2,9], and 6 to $12 \%$ are chromosomal alterations [8]. Conventional genetics was once considered the gold standard for stillbirth evaluation $[3,11,15,16,17]$. We decided to perform MLPA containing probes for chromosomes $\mathrm{X}, \mathrm{Y}, 13,18$ and 21 , to evaluate the most common chromosomal causes of stillbirth, which were not the case in our study; therefore, we cannot discard other chromosomal or genetic etiology. Chromosomal microarrays (CMA) are now considered the first line of study [16,17].

Maternal obesity $\left(\mathrm{BMI} \geq 30 \mathrm{Kg} / \mathrm{m}^{2}\right)$, has been positively associated with stillbirth [18]; however, no BMI score has been reported as secure or protective for stillbirth. In a meta-analysis by Aune et al., 18 cohorts were included to analyze BMI and stillbirth risk, finding that this association is positive for obesity and an important higher risk with a BMI of 40 [19]. In our study, $43 \%$ of the mothers had a BMI $>30$, which can account for the outcome of their pregnancies.

Pre-gestational diabetes mellitus (DM) (either type 1 or 2 ) is associated with an increased risk of fetal macrosomia, birth defects, and stillbirth at 36 to 42 weeks of gestation. Similar results have been reported in gestational diabetes [20,21,22]. Fiftyseven percent of the mothers in this study had poorly controlled pre-gestational DM, which is a high proportion compared to the $5.2 \%$ reported in another study (20). The physiopathology that explains how hyperglycemia might contribute to the events that lead to fetal death has not been fully determined. Elevation of plasma lactate was reported, predominantly in the third trimester, as a possible cause [23]. This result suggests that a lactic acid elevation leads to anaerobic metabolism, causing hypoxia, acidosis, and subsequent fetal death [24]. Obesity and diabetes are serious health problems in our country, mostly in northern Mexico, and occur in $5.2 \%$ of pregnancies [20].

It is important to establish that even if diabetes or obesity is identified as an important risk factor in a woman, a complete study of stillbirth should be done because that does not eliminate the probability of other causes.

Amongst maternal factors, infections account for $20 \%$ of stillbirths in developed countries [25]. Infections like cytomegalovirus and syphilis are frequently reported in these patients; usually, infectious etiology is not directly looked for; suspicion based on prenatal ultrasound or physical examination leads to its evaluation $[8,25]$. We identified infection risk factors by medical record data and plain X-ray.

Other maternal diseases have been implicated in stillbirth like thyroid pathologies, cardiovascular, renal, rheumatic diseases, and cancer. These conditions can be associated with stillbirth in either acute or chronic states; however, most women with these conditions can achieve live births, so they are considered important for stillbirth assessment, but causality should be evaluated in every case [8].

In Mexico, one of every 90 pregnancies are twin pregnancies. These convey a higher risk of birth defects (10 times more than singleton pregnancies) [26], as well as an increased stillbirth risk, 13 times higher in monochorionic pregnancies, and 5 times higher in dichorionic pregnancies [27].

The global strategy to end stillbirth classifies twin pregnancies as an important risk factor, recommending early delivery between 34 and 37 weeks of gestation in monochorionic pregnancies and 37 to 29 in dichorionic pregnancies [27,28,29]. Prenatal care in this scenario should be stricter.

Placental causes are attributed in $64.9 \%$ of stillbirths. Identification of placental pathology requires a microscopical and macroscopical evaluation after birth, prenatal markers are not considered useful for evaluation [30]

Placental causes may be associated with growth restriction, but not all patients present growth restriction, and the ones that do, do not all result in stillbirth [30]. We did not perform studies on the placenta, so we cannot confirm or exclude placental etiology. 
Another risk factor identified in our study was tobacco consumption. Exposure to tobacco, either active or passive, has been positively identified as a stillbirth risk factor. However, when exposure is implicated, fetal growth restriction is reported, when that significant data is lacking, the risk of stillbirth has been proposed to be like women without tobacco consumption $[18,31]$

\section{Conclusions}

We found that well-known public health problems in Mexico are present as stillbirth risk factors in our population. Diabetes and obesity are identified as the most important associations. These factors are preventable by implementing strategies that lead toward better prenatal care.

The best tools for identifying stillbirth risk factors at our institution were the obtention of a medical history, physical examination, and prenatal ultrasound; however, valuable tools such as an autopsy and genetic studies should be pursued. To increase the efficacy of an autopsy, we must reduce the time from death to study. To achieve a genetic diagnosis, we should implement studies that help identify chromosomal etiologies, not only the most frequent, but also those that are not dependent on cell culture, ideally CMA. Next-Generation Sequencing (NGS) platforms are useful when a monogenic cause is suspected.

By modifying these limitations, a long-term prospective study would be much informative to continue the study of stillbirth etiology.

\section{References}

1. Tavares Da Silva F, Gonik B, McMillan M et al (2016) Stillbirth: Case definition and guidelines for data collection, analysis, and presentation of maternal immunization safety data. Vaccine 34:6057-6068

2. Malacova E, Tippaya S, Bailey HD et al (2020) Stillbirth risk prediction using machine learning for a large cohort of births from Western Australia, 1980-2015. Scientific Reports 10

3. Castro DM, Castro Llamas J, González PG, Ríos MA (2012) Alteraciones genéticas y estrategias diagnósticas en muerte fetal. Ginecol Obstet Mex 80:313-319

4. Aminu M, Bar-Zeev S, van den Broek N (2017) Cause of and factors associated with stillbirth: a systematic review of classification systems. Acta Obstet Gynecol Scand 96:519-528

5. Murguía-Peniche T, Illescas-Zárate D, Chico-Barba G, Bhutta ZA (2016) An ecological study of stillbirths in Mexico from 2000 to 2013. Bull World Health Organ 94:322-330A

6. Pauli RM, Reiser CA (1994) Wisconsin Stillbirth Service Program: Il. Analysis of diagnoses and diagnostic categories in the first 1,000 referrals. Am J Med Genet 50:135-153

7. Holmes LB, Nasri H, Beroukhim R et al (2018) Stillborn Infants: Associated Malformations. Birth Defects Res 110:114-121

8. Silver RM, Varner MW, Reddy U et al (2007) Workup of stillbirth: a review of the evidence. Am J Obstet Gynecol 196:433444

9. Wojcik MH, Brodsky D, Stewart JE, Picker J (2018) Peri-mortem evaluation of infants who die without a diagnosis: focus on advances in genomic technology. J Perinatol 38:1125-1134

10. Tomlinson AJ, Martindale E, Bancroft K, Heazell A (2018) Improved management of stillbirth using a care pathway. Int J Health Gov 23:18-37

11. Pinar $\mathrm{H}$, Koch MA, Hawkins $\mathrm{H}$ et al (2012) The stillbirth collaborative research network postmortem examination protocol. Am J Perinatol 29:187-202

12. Lord J, McMullan DJ, Eberhardt RY et al (2019) Prenatal exome sequencing analysis in fetal structural anomalies detected by ultrasonography (PAGE): a cohort study. Lancet 393:747-757

13. Whitworth M, Bricker L, Mullan C (2015) Ultrasound for fetal assessment in early pregnancy. Cochrane Database Syst Rev

14. Man J, Hutchinson JC, Heazell AE et al (2016) Stillbirth and intrauterine fetal death: factors affecting determination of cause of death at autopsy. Ultrasound Obstet Gynecol 48:566-573

Page $7 / 13$ 
15. Page JM, Christiansen-Lindquist L, Thorsten V et al (2017) Diagnostic Tests for Evaluation of Stillbirth: Results From the Stillbirth Collaborative Research Network. Obstet Gynecol 129:699-706

16. Reddy UM, Page GP, Saade GR et al (2012) Karyotype versus microarray testing for genetic abnormalities after stillbirth. N Engl J Med 367:2185-2193

17. Rosenfeld JA, Tucker ME, Escobar LF et al (2015) Diagnostic utility of microarray testing in pregnancy loss. Ultrasound Obstet Gynecol 46:478-486

18. Gardosi J, Madurasinghe V, Williams M et al (2013) Maternal and fetal risk factors for stillbirth: population based study. BMJ 346:f108-f108

19. Aune D, Saugstad OD, Henriksen T, Tonstad S (2014) Maternal body mass index and the risk of fetal death, stillbirth, and infant death: a systematic review and meta-analysis. JAMA 311:1536-1546

20. Tennant PWG, Glinianaia SV, Bilous RW et al (2014) Pre-existing diabetes, maternal glycated haemoglobin, and the risks of fetal and infant death: a population-based study. Diabetologia 57:285-294

21. Rosenstein MG, Cheng YW, Snowden JM et al (2012) The risk of stillbirth and infant death stratified by gestational age in women with gestational diabetes. Am J Obstet Gynecol 206:309.e1-309.e7

22. Stacey T, Tennant $P$ (2019) Authors' reply re: Gestational diabetes and the risk of late stillbirth: a case-control study from England. UK BJOG 126:1184-1184

23. Bradley RJ, Brudenell JM, Nicolaides KH (1991) Fetal acidosis and hyperlacticaemia diagnosed by cordocentesis in pregnancies complicated by maternal diabetes mellitus. Diabet Med 8:464-468

24. Dudley DJ (2007) Diabetic-associated stillbirth: incidence, pathophysiology, and prevention. Clin Perinatol 34:611-626, vii

25. Page JM, Bardsley T, Thorsten V et al (2019) Stillbirth associated with infection in a diverse US cohort. Obstetrics Gynecology 134:1187-1196

26. López-Uriarte A, Aguinaga-Ríos M (2012) Discordancia de defectos congénitos en recién nacidos de embarazos múltiples en el Instituto Nacional de Perinatología. Perinatol Reprod Hum 26:08-16

27. Cheong-See F, Schuit E, Arroyo-Manzano D et al (2016) Prospective risk of stillbirth and neonatal complications in twin pregnancies: systematic review and meta-analysis. BMJ 354:i4353

28. American College of Obstetricians and Gynecologists, Society for Maternal-Fetal Medicine (2014) ACOG Practice Bulletin No. 144: Multifetal gestations: twin, triplet, and higher-order multifetal pregnancies. Obstet Gynecol 123:1118-1132

29. Visintin C, Mugglestone MA, James D et al (2011) Antenatal care for twin and triplet pregnancies: summary of NICE guidance. BMJ 343:d5714-d5714

30. Bukowski R, Hansen NI, Pinar H et al (2017) Altered fetal growth, placental abnormalities, and stillbirth. PLoS One 12:e0182874

31. Flenady V, Koopmans L, Middleton P et al (2011) Major risk factors for stillbirth in high-income countries: a systematic review and meta-analysis. Lancet 377:1331-1340

\section{Tables}

Table 1. Maternal socio-demographic characteristics 


\begin{tabular}{ll}
\hline Characteristic & Value \\
\hline Age range, yrs (median) & $18-38(25)$ \\
Substance abuse† (\%) & $5 / 21(23.8)$ \\
\hline Smoking & $4 / 5(80)$ \\
\hline Alcohol & $3 / 5(60)$ \\
\hline Illegal drugs & $1 / 5(20)$ \\
\hline Maternal diseases ††(\%) & $9 / 21(43)$ \\
\hline Diabetes mellitus & $4 / 9(44.4)$ \\
\hline Syphilis & $2 / 9(22.2)$ \\
\hline HIV & $1 / 9(11.1)$ \\
\hline Polycystic ovary syndrome & $1 / 9(11.1)$ \\
\hline Acute pancreatitis & $1 / 9(11.1)$ \\
\hline Colon cancer & $1 / 9(11.1)$ \\
\hline Elevated antepartum BMI & $12 / 21(57)$ \\
\hline Overweight $\left(\geq 25<30 \mathrm{~kg} / \mathrm{m}^{2}\right)$ & $3 / 12(25)$ \\
\hline Obese (>30 kg/m $\left.{ }^{2}\right)$ & $9 / 12(75)$ \\
\hline
\end{tabular}

† Two patients consumed more than one substance.

$\dagger+$ One patient had two diseases

Table 2. Stillbirth demographic characteristics 


\begin{tabular}{|c|c|}
\hline Characteristic & n (\%) \\
\hline \multicolumn{2}{|c|}{ Gestation number } \\
\hline Primigravida & $10(47.6)$ \\
\hline Second to third & $6(28.5)$ \\
\hline More than 3 & $5(23.8)$ \\
\hline \multicolumn{2}{|c|}{ Weeks of gestation } \\
\hline 22 to 28 & 4 (19) \\
\hline 29 to 37 & $14(66.6)$ \\
\hline More than 37 & $3(14.2)$ \\
\hline \multicolumn{2}{|l|}{ Type of delivery } \\
\hline Vaginal & $18(85.7)$ \\
\hline C-section & $3(14.2)$ \\
\hline \multicolumn{2}{|l|}{ Gender } \\
\hline Female & $12(57)$ \\
\hline Male & $9(42.8)$ \\
\hline \multicolumn{2}{|l|}{ Weight } \\
\hline $500-999 \mathrm{~g}$ & $8(38)$ \\
\hline $1000-1999 \mathrm{~g}$ & $6(28.5)$ \\
\hline $2000-2499 \mathrm{~g}$ & $1(4.7)$ \\
\hline$>2500 \mathrm{~g}$ & 6 (28.5) \\
\hline \multicolumn{2}{|c|}{ Degree of fetal maceration } \\
\hline Grade 0 & $1(4.7)$ \\
\hline Grade I & $16(76.1)$ \\
\hline Grade II & $2(9.5)$ \\
\hline Grade III & $2(9.5)$ \\
\hline
\end{tabular}

Table 3. Summary of stillbirths with birth defects and twin pregnancies, with risk factors of importance 


\begin{tabular}{|c|c|c|c|c|c|c|c|c|}
\hline Patient & Gender & Weeks & $\begin{array}{l}\text { Prenatal } \\
\text { ultrasound }\end{array}$ & $\begin{array}{l}\text { Fetal } \\
\text { Dysmorphology }\end{array}$ & X-ray & Autopsy & MLPA & $\begin{array}{l}\text { Maternal/Fetal } \\
\text { risk factors }\end{array}$ \\
\hline 1 & Female & 33 & $\begin{array}{l}\text { Alobar } \\
\text { holoprosencephaly, } \\
\text { parietal } \\
\text { meningocele, } \\
\text { perimembranous } \\
\text { ventricular septal } \\
\text { defect, cleft lip and } \\
\text { palate, single } \\
\text { umbilical artery }\end{array}$ & $\begin{array}{l}\text { Upslanted } \\
\text { palpebral } \\
\text { fissures, right } \\
\text { cleft lip and } \\
\text { palate, right } \\
\text { degree } 2 \\
\text { microtia, } \\
\text { aplasia cutis in } \\
\text { scalp, single } \\
\text { umbilical } \\
\text { artery }\end{array}$ & $\begin{array}{l}\text { Not } \\
\text { performed }\end{array}$ & Not performed & Normal & $\begin{array}{l}\text { Mother with type } \\
2 \text { pregestational } \\
\text { diabetes with } \\
\text { poor metabolic } \\
\text { control }\end{array}$ \\
\hline 2 & Male & 29 & Normal & Normal & $\begin{array}{l}\text { Not } \\
\text { performed }\end{array}$ & Not performed & Normal & $\begin{array}{l}\text { Mother with } \\
\text { colon cancer } \\
\text { diagnosed at } \\
\text { second } \\
\text { trimester; } \\
\text { treated with } \\
\text { rifampicin, } \\
\text { oxaliplatin and 5- } \\
\text { fluorouracil; } \\
\text { cancer lead to } \\
\text { maternal death }\end{array}$ \\
\hline 3 & Female & 31 & Not performed & Normal & Normal & Not performed & Normal & $\begin{array}{l}\text { Mother with } \\
\text { polycystic ovary } \\
\text { syndrome }\end{array}$ \\
\hline 4 & Female & 22.6 & Not performed & Normal & Normal & Not performed & Normal & $\begin{array}{l}\text { Mother with type } \\
2 \text { pregestational } \\
\text { diabetes with } \\
\text { poor metabolic } \\
\text { control }\end{array}$ \\
\hline 5 & Male & 30 & Anencephaly & Anencephaly & Normal & Not performed & Normal & $\begin{array}{l}\text { Maternal } \\
\text { Obesity }\end{array}$ \\
\hline 6 & Male & 30.1 & Hydrops fetalis & Ascites & Normal & Not performed & Normal & Hydrops fetalis \\
\hline 7 & Female & 34.1 & Normal & Normal & Normal & Not performed & Normal & None identified \\
\hline 8 & Female & 34.2 & $\begin{array}{l}\text { Hyperechogenic } \\
\text { bowel, scalp, and }\end{array}$ & Normal & $\begin{array}{l}\text { Congenital } \\
\text { syphilis }\end{array}$ & Not performed & Normal & $\begin{array}{l}\text { Mother with } \\
\text { overweight, HIV }\end{array}$ \\
\hline
\end{tabular}




\begin{tabular}{|c|c|c|c|c|c|c|c|c|}
\hline & & & $\begin{array}{l}\text { abdominal wall } \\
\text { edema }\end{array}$ & & $\begin{array}{l}\text { bone } \\
\text { lesions }\end{array}$ & & & and syphilis. \\
\hline 9 & Male & 27.3 & $\begin{array}{l}\text { Cleft lip and } \\
\text { palate, } \\
\text { holoprosencephaly, } \\
\text { polydactyly }\end{array}$ & $\begin{array}{l}\text { Upslanted } \\
\text { palpebral } \\
\text { fissures, } \\
\text { depressed } \\
\text { nasal bridge, } \\
\text { central cleft lip } \\
\text { and palate, left } \\
\text { preauricular } \\
\text { tags, left upper } \\
\text { extremity } \\
\text { preaxial } \\
\text { polydactyly }\end{array}$ & $\begin{array}{l}\text { Not } \\
\text { performed }\end{array}$ & $\begin{array}{l}\text { Alobar } \\
\text { holoprosencephaly, } \\
\text { immature organs, } \\
\text { cause of death: } \\
\text { malformations } \\
\text { incompatible with } \\
\text { life. }\end{array}$ & Normal & $\begin{array}{l}\text { Mother with } \\
\text { pregestational } \\
\text { type } 1 \text { diabetes }\end{array}$ \\
\hline 10 & Male & 31 & Not performed & Normal & Normal & Not performed & Normal & $\begin{array}{l}\text { Mother with } \\
\text { overweight and } \\
\text { syphilis }\end{array}$ \\
\hline 11 & Female & 39 & Normal & Normal & Normal & Not performed & Normal & Maternal obesity \\
\hline 12 & Female & 32 & $\begin{array}{l}\text { Intrauterine } \\
\text { growth restriction } \\
\text { since week } 22^{\text {nd }}\end{array}$ & $\begin{array}{l}\text { Bilateral pes } \\
\text { varus }\end{array}$ & $\begin{array}{l}\text { Not } \\
\text { performed }\end{array}$ & Not performed & Normal & Twin pregnancy \\
\hline 13 & Male & 33 & Normal & $\begin{array}{l}\text { Terminal } \\
\text { transverse } \\
\text { limb defect in } \\
\text { left upper } \\
\text { extremity }\end{array}$ & $\begin{array}{l}\text { Not } \\
\text { performed }\end{array}$ & $\begin{array}{l}\text { Acute } \\
\text { chorioamnionitis, } \\
\text { acute thymic } \\
\text { involution, } \\
\text { immature organs, } \\
\text { advanced autolysis }\end{array}$ & Normal & $\begin{array}{l}\text { Maternal obesity } \\
\text { and } \\
\text { pregestational } \\
\text { type } 2 \text { diabetes } \\
\text { with poor } \\
\text { metabolic } \\
\text { control }\end{array}$ \\
\hline 14 & Male & 34 & Not performed & Normal & Normal & Not performed & Normal & $\begin{array}{l}\text { Maternal } \\
\text { overweight, twin } \\
\text { pregnancy }\end{array}$ \\
\hline 15 & Female & 30 & Normal & Normal & Normal & Not performed & Normal & $\begin{array}{l}\text { Maternal } \\
\text { obesity, acute } \\
\text { pancreatitis that } \\
\text { required surgical } \\
\text { intervention }\end{array}$ \\
\hline 16 & Female & 22.1 & Normal & Normal & Normal & Not performed & Normal & $\begin{array}{l}\text { Maternal } \\
\text { obesity, }\end{array}$ \\
\hline
\end{tabular}


advanced

maternal age

\begin{tabular}{|c|c|c|c|c|c|c|c|c|}
\hline 17 & Female & 29 & $\begin{array}{l}\text { Complete placenta } \\
\text { previa }\end{array}$ & Normal & Normal & Not performed & Normal & $\begin{array}{l}\text { Maternal } \\
\text { obesity, } \\
\text { advanced } \\
\text { maternal age, } \\
\text { placenta previa }\end{array}$ \\
\hline 18 & Female & 32 & $\begin{array}{l}\text { Oligohydramnios, } \\
\text { double nuchal cord }\end{array}$ & Normal & Normal & Not performed & Normal & $\begin{array}{l}\text { Maternal } \\
\text { obesity, } \\
\text { oligohydramnios, } \\
\text { nuchal cord }\end{array}$ \\
\hline 19 & Male & 29 & $\begin{array}{l}\text { Frontoparietal } \\
\text { bilateral } \\
\text { porencephaly, } \\
\text { intracranial } \\
\text { hemorrhage } \\
\text { (grade I), } \\
\text { microcephaly, } \\
\text { corpus callosum } \\
\text { hypoplasia, } \\
\text { cerebellar vermis } \\
\text { hypoplasia, small } \\
\text { for gestational } \\
\text { age, } \\
\text { hyperechogenic } \\
\text { bowel, } \\
\text { oligohydramnios. }\end{array}$ & $\begin{array}{l}\text { Hypertelorism, } \\
\text { pterygium in } \\
\text { elbows, knees, } \\
\text { and feet }\end{array}$ & 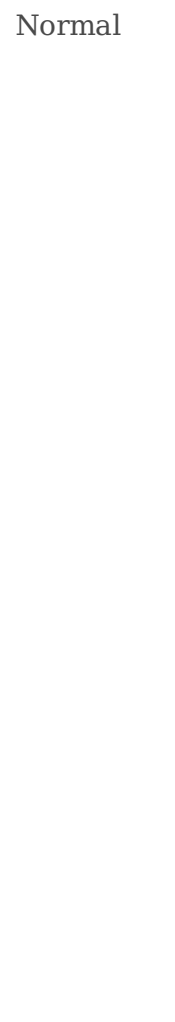 & 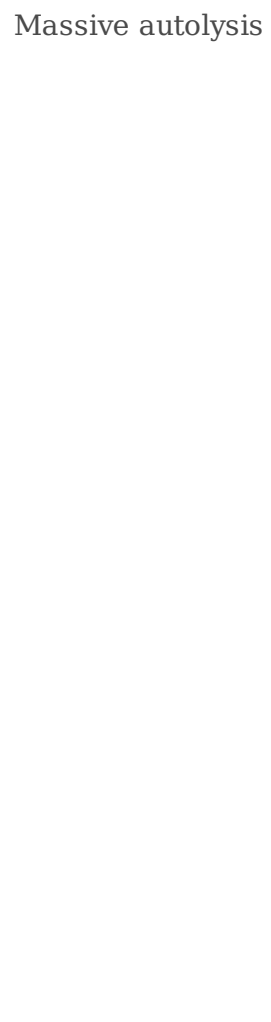 & 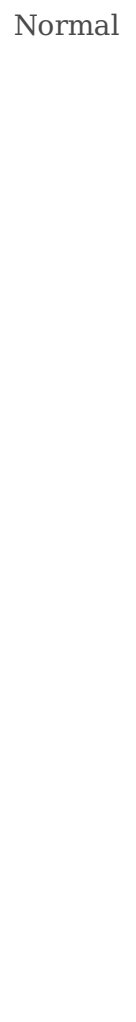 & $\begin{array}{l}\text { No risk factor, } \\
\text { monogenic } \\
\text { cause suspected, } \\
\text { probable lethal } \\
\text { multiple } \\
\text { pterygium } \\
\text { syndrome }\end{array}$ \\
\hline 20 & Male & 35.1 & Normal & $\begin{array}{l}\text { Bilateral pes } \\
\text { varus }\end{array}$ & $\begin{array}{l}\text { Not } \\
\text { performed }\end{array}$ & Not authorized & Normal & $\begin{array}{l}\text { Maternal } \\
\text { obesity, fetus } \\
\text { with weight } \\
\text { above } 90^{\text {th }} \\
\text { percentile }\end{array}$ \\
\hline 21 & Female & 38 & Normal & Normal & $\begin{array}{l}\text { Not } \\
\text { performed }\end{array}$ & Not authorized & Normal & $\begin{array}{l}\text { Maternal } \\
\text { obesity, fetus } \\
\text { with weight } \\
\text { above } 90^{\text {th }} \\
\text { percentile }\end{array}$ \\
\hline
\end{tabular}

